Article received on $30^{\text {th }}$ September 2014

Article accepted on $2^{\text {nd }}$ October 2014

UDC: 78.038 .42

111.1:78.01

\title{
Andrija Filipovic**
}

University of Arts in Belgrade

Interdisciplinary Studies, Theory of Arts and Media

\section{HUMAN, ALL TO HUMAN: BARE REPETITION AND ORGANISM IN MINIMAL MUSIC}

\begin{abstract}
The main thesis in this work is that minimalism produces neutral sensory perception and is thereby complicit not only in the production of the body qua organism, but also in the wider socio-politico-economic environment that such a conception of the body entails. Minimalism produces neutral sensory perception by insisting on "bare repetition", the literal, direct, and immediate materiality of the work of art; in other words, it insists on a specific ontological relation between difference and the same, whereby the same, singular, and identical, predicated on representational thought, replace the different, which is expressed in becoming. Minimalism, neutral perception, the relative immanence of capitalism, and the body qua organism constitute a sort of chain, which should be subjected to critical analysis and a critique based on the concepts of difference, event, and encounter.
\end{abstract}

Keywords: minimalism, repetition, organism, ontology, the body, sensory perception

In this work, I explore the relationship between Deleuze and Guattari's ontology and minimal music. More precisely, I will show that, by insisting on the literality of the work of art and "bare repetition", minimalism produces neutral sensory perception, whereby it collaborates in maintaining a certain image of the human and the body qua organism. "Literality" here denotes those "works of art that are produced neither as images nor statues, but as literally and directly present objects that affirm their material, spatial, and temporal presence". ${ }^{1}$

\footnotetext{
* Author contact information: endymion23@gmail.com

${ }^{1}$ Miško Šuvaković, Pojmovnik suvremene umjetnosti, Zagreb, Horetzsky, 2005, 149, emphasis mine.
} 
Artists who insist on the literality of their works by affirming their material, spatial, and temporal presence deny the potential symbolic, metaphoric, and aesthetic functions that might be ascribed to a work of art. The focus is thus on the here and now of the work of art, on its direct and immediate materiality. "Bare repetition" is a concept in Deleuze and Guattari's philosophy and ontology that signifies not mere repetition as it is understood in everyday life, but an ontological relation between the same and difference. "Bare repetition" is the same, the one, and the identical that rests on representational thought and "suppresses" all difference. Linked with representational thought, "bare repetition" is also connected with the lived as well as the entire field of the reactive in the Nietzschean sense, that is, with the domain of life and the living. By contrast, there needs to be a violent encounter between the body and sound, which may potentially disorganize the hierarchical ordering of the organs and thus open lines of flight. There needs to be an encounter to produce difference.

In 1970, curator Marcia Tucker wrote her "PheNAUMANology", an essay on Bruce Nauman published by Artforum, where she made the following points:

This concern with physical self is not simple artistic egocentrism, but use of the body to transform intimate subjectivity into objective demonstration. Man is the perceiver and the perceived; he acts and is acted upon; he is the sensor and the sensed. His behaviour constitutes a dialectical interchange with the world he occupies. ${ }^{2}$

Several decades later, she remarked in another conversation:

Something unusual was in the air, an eccentric view of what art might be. It's important to remember that there was a huge amount of interest in phenomenology in the art world at that time ... and people were very excited by the idea that art didn't have to be about what you perceived but about the very act of perception. This interest largely manifested itself in sculpture, like Bruce Nauman's early work, for example - thinking about art not in terms of objects but as a catalyst for experience on the part of the viewer. ${ }^{3}$

At that time, new strategies in art, roughly speaking, involved attempts to dismantle the boundaries between high and low art and overcome the limitations of high modernism. Minimalism sought to achieve that by presenting the object of art literally ("meaning is realized by the phenomenality, appearance, and literal presence of a specific object and installation"), eliminating the presence of the artist from the artwork, privileging instead the viewer's active perception ("meaning is realized by theatricalizing the perception of the work of art, which

${ }^{2}$ Cf. Marcia Tucker, "PheNEUMANology", Artforum, 1970, 9/4, 1970, 38-44, emphasis mine.

${ }^{3}$ Michael Lobel, "Sign Language”, Artforum, 2003, 42/1, 126-132, emphasis mine. 
means that the viewer is forced actively to perceive the object or installation, moving around and inside it"), and, finally, by exploring the conceptual as well as structural conditions of the emergence of the work of art. ${ }^{4}$ Searching for ways of problematizing the conventions of high art, artists sought to liken art to life by including found objects, using non-artistic materials that were often perishable or were industrial in origin, or by integrating the artwork with the space occupied by the viewer and by actively engaging the latter. ${ }^{5}$ The resulting problematization of the boundaries of art and the artistic by using everyday objects and actively involving the viewer's perception have "resulted in a shift of emphasis: away from a basic concern for form reduction and formal relationships and toward the varieties of experience which surround the perception of form". ${ }^{6}$

The quest for alternative artistic practices led toward various strategies and, according to Jonathan Bernard, one might single out three of those practices that are common to both music and the visual arts: the reduction of chance, the emphasis on surfaces, and the focus on the whole, which also accomplishes a reduction in the number of elements. ${ }^{7}$ The reduction of chance, if not its total elimination, from the process of making a work of art was, among other things, a response to abstract expressionism and action painting. Donald Judd once said that it made more sense to "use a simple form that doesn't look like either order or disorder", such as a box, which "does have an order, but it's not so ordered that that's the dominant quality". ${ }^{8}$

Emphasizing the surface of the artwork was aimed at accomplishing a sort of depersonalization, that is, erasure of the trace of the artist in the work of art. In that regard, painter Kenneth Noland said: "The thing is to get that color down on the thinnest conceivable surface, a surface sliced into the air as if by a razor. It's all color and surface, that's all". ${ }^{9}$ By extension, sculptors use steel and its polished surface, discussed by one critic as follows:

The smoothness and general uninflectedness of surface in a good many of the pieces might stand as a metaphor for the general smoothing over of details of execution - a

${ }^{4}$ Cf. Miško Šuvaković, Pojmovnik suvremene umjetnosti, op. cit., 374.

${ }^{5}$ Cf. Nicole de Armendi, Phenomenological Labyrinths in 1960s and 1970s American Art, Virginia Commonwealth University, 2009, 49 (unpublished manuscript).

${ }^{6}$ Jack Burnham, Beyond Modern Sculpture, Braziller, New York, 1968, 173.

${ }^{7}$ Cf. Jonathan W. Bernard, "The Minimalist Aesthetic in the Plastic Arts and in Music", Perspectives of New Music, 1993, 31/1, 95.

${ }^{8}$ Bruce Glaser, "Questions to Stella and Judd: Interview", in: Gregory Battcock (ed.), Minimal Art: A Critical Anthology, New York, E. P. Dutton, 1968, 156.

9 E. A. Carmean, "Modernist Art 1960 to 1970", quoted in: Jonathan W. Bernard, "The Minimalist Aesthetic in the Plastic Arts and in Music", 97. 
metaphor that becomes richer in light of the fact that some of the new work is produced according to specifications at a factory. ${ }^{10}$

The simplification of musical material is analogous to the "smoothness" and the "non-pictorial" in the visual arts. This is reflected in the limited repertoire of sound sources and the use of repetition. The aim of repetition is precisely to evoke the feeling of "flatness", the smoothness of flat surfaces, behind which there is nothing to attract the listener's attention, which, however, does not imply a simplification in the perception of such music - "Simplicity of shape does not necessarily equate with simplicity of experience", according to Robert Morris. ${ }^{11}$

Focusing on the body as a whole rather than on its constituent parts was meant to enable easier and clearer communication with the viewers and listeners. Carl Andre solved the problem of relating the artwork as a whole to its constituent parts by using identical bricks, which thus "did not lend themselves to relational structures", since "any part could replace any other part". ${ }^{12}$ When it comes to music, an illustration of this "principle" may be found in Alvin Lucier's I Am Sitting in a Room, whose sole material for this piece was his own voice, which he recorded and then re-recorded the recorded material thus obtained. During the course of the piece, one pays less and less attention to its constituent parts, in favour of the totality of the recorded voice. The reduction of constituent elements and materials suggests that "the work of art is not primarily determined by material, spatial, or visual aspects, but by a conceptual plan and structural project imposed on an object or installation". ${ }^{13}$ The relationship between structural elements led toward a Gestalt conception, that is, the laws of visual wholeness and good forms. ${ }^{14}$ This in turn means that the given elements are connected so as to form a certain whole that permits perceiving precisely the elements that constitute it. The Gestalt conception generated a serial understanding of structure:

A series is an array of consecutive elements that correspond to a numerical series or progression, as well as to a linguistic syntagm. Transformations of a Gestalt into a series suggest transformations of the two-dimensional configuration of the Gestalt of an image or the three-dimensional configuration of an object into a one-dimensional

\footnotetext{
${ }^{10}$ Michael Benedikt, "Sculpture as Architecture: New York Letter, 1966-67", in: Gregory Battcock (ed.), Minimal Art: A Critical Anthology, op. cit., 88.

${ }^{11}$ Robert Morris, "Statement", quoted in: Jonathan W. Bernard, "The Minimalist Aesthetic in the Plastic Arts and in Music", 101.

${ }^{12}$ David Bourdon, "The Razed Sites of Carl Andre", in: Gregory Battcock (ed.), Minimal Art: A Critical Anthology, op. cit., 104.

${ }^{13}$ Miško Šuvaković, Pojmovnik suvremene umjetnosti, op. cit., 374.

${ }^{14}$ Cf. ibid., 375.
} 
(linear) order of an array of elements. In minimal art, the series or array is conceived as a simple series, i.e., the point is not about the complex logic of the law of a series, but the literality and self-reflexive simplicity of arranging elements. By being placed in a series, an object (element) acquires its value by virtue of opposing the element that precedes or follows it, or both. The concept of series maintains the concept of unity, but, unlike that of a Gestalt, this unity is conceptual, not optical. ${ }^{15}$

These three strategies or "principles" were meant to present the literal objectivity of the artwork, whether a painting, statue, or composition in sound, whereby "an earmark of minimalist art is the tendency to locate content outside the art object, in its physical setting or in the viewer's responses, rather than 'inside' it". ${ }^{16}$ The work of art becomes factual, concrete, and self-evident. ${ }^{17}$ Thus La Monte Young in "\#4" of his Compositions 1960 series alters the relationship between the performer and the audience. At the beginning of the piece, the lights go off for a period of time announced beforehand, and at the end of the piece the audience is informed that their activities during that time may have been part of the performance of the piece. In another piece, "\#6", the performers on stage imitate the usual activities of the audience sitting in their seats in the hall or at the bar of a restaurant. ${ }^{18}$ By means of activating perception, La Monte Young focused on the relationship of the viewer/listener and the artwork also by combining installations in light with drones, in his so-called Dream Houses, which went on for several months, even years. Zazeela and La Monte Young's installations in light and sound, comprising objects made of aluminum and suspended on transparent strips, with intense light shining on them, left the following impression:

The effect is a unique and extraordinary transvaluation of perception: the mobiles seem to hover unanchored, while the shadows they cast in various hues attain an apparent solidity against the light-dissolved walls equal to their literally palpable but apparently disembodied sources. Like Young's music, to which it serves as an almost uncanny complement, Zazeela's work is predicated upon the extended duration necessary to experience the nuances which are its essence. ${ }^{19}$

In this way, Zazeela and Young generated an effect of a dematerialization of reality, as well as, consequently, a feeling of shifting consciousness and mode of

\footnotetext{
${ }^{15}$ Ibid.

${ }^{16}$ Kenneth Baker, Minimalism: Art of Circumstance, New York, Abbeville Press, 1988, 21.

${ }^{17}$ Cf. Barbara Rose, “ABC Art”, in: Gregory Battcock (ed.), Minimal Art: A Critical Anthology, op. cit., 290-291.

${ }^{18}$ Cf. Edward Strickland, Minimalism: Origins, Bloomington and Indianapolis, Indiana University Press, 2000, 139.

${ }^{19}$ Ibid., 155.
} 
perception. ${ }^{20}$ Likewise, immersion was the aim of other pieces by Young where he used drones, such as The Tortoise, His Dreams and Journeys, a piece to which Young still refers as unfinished, performed over the years in various ways and under different titles, but always featuring greatly extended notes and an almost deafening volume:

One musician plays a viola that has been modified to allow the production of sound from three strings with equal intensity, another plays double-stops on a violin reinforced by a resonating string, while Young and his wife vocally produce other tones, in equally strict just intonation, so accurately that the resulting accumulation of tones sounds almost orchestral. Nothing else happens, except when Young from time to time enters vocally with the lowest tone of the ensemble. [...] My two hours of listening paid tribute to a unique musical experience. The ritualistic self-sufficiency ... must be heard to be believed. In sound at least. Young has got very close to the psychological nerve of ritual. ${ }^{21}$

Young intended - with some success, too - the relentless repetitiveness of his drones to trigger certain emotional states in his listeners, that is, to induce them to link certain tones and drones with certain feelings: "There is evidence, he claims, that specific frequencies always travel through specific pathways of the auditory system, and are thus capable of inducing specific psychological states. By exposure to extreme forms of sound durations it is possible to become conscious of the relationship between specific frequencies and the psychological and emotional states they create". ${ }^{22}$ But the problem lies precisely in that repetitive and reductionist approach. Why is it a problem? Briefly, minimalist reductionism introduces transcendence into immanence: "when immanence becomes immanent 'to' a transcendental subjectivity, it is at the heart of its own field that the hallmark or figure of a transcendence must appear as action now referring to another self, to another consciousness (communication)". ${ }^{23}$

Minimalism does this by setting out from what is "given" and by giving it the way it appears to the subject, or, as Miško Šuvaković put it: "An array of four or six steel boxes has nothing in common with the universal metaphysical order, but only with a direct and literal perception of a local array appearing to the viewer" ${ }^{24}$ This giving of a literal object reveals that the main way of relating to and cognizing phenomena is the subject's orientation toward the phenomena. The lived, as multiplicities or perceptive-affective assemblages, serve minimal-

\footnotetext{
${ }^{20}$ Cf. ibid., 164-165.

${ }^{21}$ Ibid., 159.

22 Ibid., 287.

${ }^{23}$ Gilles Deleuze and Félix Guattari, What Is Philosophy?, London, Verso, 2009, 46.

${ }^{24}$ Miško Šuvaković, Pojmovnik suvremene umjetnosti, op. cit., 375, emphasis mine.
} 
ism only to ground the actions of subjectivity, with which such a subject first establishes a "sensory world filled with objects, then an intersubjective world occupied by the other, and finally a common ideal world that will be occupied by scientific, mathematical, and logical formations". ${ }^{25}$ Deleuze and Guattari refer to the lived as proto-beliefs or Ur-doxa, original opinions as utterances, whereby actions of transcendence cut through multiplicity and determine the meanings of the potential totality of the lived. It thereby emerges that immanence is only that of the lived that belongs to a subject whose actions will be concepts connected to that lived.

Opinion or doxa is a thought that emerges in line with recognition, that is, "recognition of a quality in perception (contemplation), recognition of a group in affection (reflection), and recognition of a rival in the possibility of other groups and other qualities (communication)". ${ }^{26}$ As communication, opinion is the universal liberal opinion, that is, consensus comprising only "the cynical perceptions and affections of the capitalist himself". ${ }^{27}$ The production process of capitalist perceptions consists of the codification of fluxes on the body of society, that is, socius. What does capitalism do and how precisely does it do it and what is the relationship between the state and capitalism? Between the state and all social formations and the axiomatic of capitalism there is an isomorphic relation. ${ }^{28}$ That means that states, as well as various other social formations, as models of the realization of the capitalist axiomatic may exist in various forms - democratic, totalitarian, socialist - and that regardless of their socio-political ordering may partake in the immanent axiomatic of the capitalist machine. The heterogeneity of forms of government is one of the things that the capitalist axiomatic readily accepts and, in fact, entails. ${ }^{29}$ A model of realization means that in the capitalist axiomatic, states are not abolished, even though there is only one capitalist global market, but, rather, assume the function of mediators in the realization of an abstract and general axiomatic that exceeds them. "States are [...] immanent models of realization for an axiomatic of decoded flows". ${ }^{30}$ As a model of realizing the capitalist axiomatic, the state mediates and performs two functions: machinic enslavement and social subjection. "Machinic enslavement" denotes the process whereby humans, along with other living beings and

\footnotetext{
${ }^{25}$ Gilles Deleuze and Félix Guattari, What Is Philosophy?, op. cit., 142.

${ }^{26}$ Ibid., 145-146.

${ }^{27}$ Ibid., 146.

${ }^{28}$ Cf. Gilles Deleuze and Félix Guattari, A Thousand Plateaus: Capitalism and Schizophrenia, Minneapolis and London, University of Minnesota Press, 1987, 445.

${ }^{29} \mathrm{Cf}$. ibid.

${ }^{30}$ Ibid., 455.
} 
inanimate objects, are subjected to the control of a higher unity, as constitutive elements of the social machine, which thus also attains the purpose of social subjection. Social subjection is a correlate of the subjection that capitalism enforces as an axiomatic of decoded flows. Namely, as a model of realizing the abstract axiomatic of capitalism, the state mediates between capital and people by inventing ever new ways of machinic enslavement and subjection as the production process of subjects, assigning identity in terms of sex, gender, body, ethnicity, profession, and so on. Hence, for example, the emergence of nations and nation states. ${ }^{31}$ On the one hand, therefore, social subjection produces individual subjects with their consciousnesses, ideas, and behaviors, while on the other hand, machinic subjection acts on pre-individual and supra-individual levels. ${ }^{32}$ Both processes are simultaneously at work.

Minimalism turns opinion into proto-opinion (Ur-doxa), which comprises culture and art as expressions of a subject who forms a community and communication within that community. However, by referring to the lived, by turning immanence into something that is immanent to the subject, minimalism forms "opinions that already extracted clichés from new perceptions and promised affections". ${ }^{33}$ Minimalism does nothing but form the opinions of the capitalist, the majority, whose perceptions are mere clichés and their affections labels of communication (which is marketing) ${ }^{34}$ and whom no art can escape unless it gets out of the cycle of lived perceptions and affections. Perception and affection turn into the reversibility of the subject and object, which generates original opinion:

[...] flesh of the world and flesh of the body as correlates that inter-change, an ideal coincidence. A curious Fleshism inspires this final avatar of phenomenology and plunges it into the mystery of the incarnation. It is both a pious and a sensual notion, a mixture of sensuality and religion, without which, perhaps, flesh could not stand up by itself (it would slide down the bones, as in Bacon's figures). The question of whether flesh is adequate to art can be put in this way: can it support percept and affect, can it constitute the being of sensation, or must it not itself be supported and pass into other powers of life? $?^{35}$

Put briefly, art should not link the subject and the world. A work of art is no more than a block of sensations, a being of sensory impressions, made of

\footnotetext{
${ }^{31}$ Cf. ibid., 503-504.

${ }^{32}$ Cf. Maurizio Lazzarato, Signs and Machines: Capitalism and the Production of Subjectivity, Los Angeles, Semiotext(e), 2014, 12.

${ }^{33}$ Gilles Deleuze and Félix Guattari, What Is Philosophy?, op. cit., 150.

${ }^{34} \mathrm{Cf}$. ibid.

${ }^{35}$ Ibid., 178.
} 
percepts and affects: "the being of sensation is not the flesh but the compound of nonhuman forces of the cosmos, of man's nonhuman becomings, and of the ambiguous house that exchanges and adjusts them, makes them whirl around like winds" ${ }^{36}$ Lived perceptions must lead to percept, lived affections to affect, because the cycle of established clichés must be broken and the already lived must be rejected, transected, as it is, with majority opinion, which is in turn predicated on a specific structure of the subject and organization of the body. This structure is the subject qua subject of judgment, and organic concept and the body as an organism. The doctrine of judgment presupposes that the human being is shaped according to a certain form and certain aim. ${ }^{37} \mathrm{~A}$ multitude of affects is separated and distributed according to a higher form - whether that higher form be God, or, in contemporary circumstances, neoliberal capitalism, which has assumed a transcendental function. In both cases, privatized organs are formed (in terms of separation and ownership) on a body without organs: "judgment implies a veritable organization of the bodies through which it acts: organs are both judges and judged, and the judgment of God is nothing other than the power to organize to infinity. Whence the relationship between judgment and the sense organs" ${ }^{38}$ In other words, this is an instance of a reactive shaping of organs and the organism.

Nietzsche's concepts of reactive and active refer to forces. According to Deleuze's Nietzsche, there is nothing but forces in mutual relations and every relation of forces constitutes a body, whether political, social, biological, or inorganic. Since the body constitutes a relation of multiple forces, "the body is a multiple phenomenon, its unity is that of a multiple phenomenon, a 'unity of domination"" ${ }^{39}$ From this follows the distinction between active and reactive forces - active forces are the superior and dominant forces in a singular body, whereas reactive forces are inferior forces, that is, those that are dominated. The distinction of forces (whether they are active or reactive) originates from their quantity (the degree of their presence). The problem is how to assess that difference precisely and accurately. As a category, quantity is inseparable from a difference in quantity, which means that the difference between forces must be assessed in terms of intensity, because the difference between forces is neither a quantitative nor a qualitative category, but a matter of intensity. Although inferior forces are established as reactive, they still perform a significant role in "secur-

\footnotetext{
${ }^{36}$ Ibid., 183.

${ }^{37}$ Cf. Gilles Deleuze, “To Have Done with Judgement”, in: Gilles Deleuze: Essays Clinical and Critical, London, Verso, 1998, 128.

${ }^{38}$ Ibid., 130.

${ }^{39}$ Gilles Deleuze, Nietzsche and Philosophy, New York, Columbia University Press, 2006, 40.
} 
ing mechanical means and final ends, by fulfilling the conditions of life and the functions and tasks of conservation, adaptation and utility". ${ }^{40}$ Herein lies one of Nietzsche's more significant insights, namely, that reactive forces determine the horizon of life and the living, because they are the ones that form the final purposes and ends and supply the means for attaining them. They are the ones that define the purposes of an organism and keep it alive by means of reactive formations such as consciousness, memory, habits, as well as eating, reproducing, preservation, and adaptation. By contrast, active forces are determined by means of appropriation, subjection, possession, and domination, that is, the abilities of metamorphosis and transformation. ${ }^{41}$

Reactive forces, those that form the living, rest on equating quantities, but Nietzsche "invokes the rights of difference in quality against quantity; he invokes the rights of difference in quantity against equality, of inequality against equalisation of quantities" for the sake of establishing the concept of eternal return, which Deleuze reinterprets as "not the 'same' or the 'one' which comes back in the eternal return but return is itself the one which ought to belong to diversity and to that which differs", ${ }^{42}$ thus as difference itself, which constitutes the plane of immanence and is reflected in becoming. Nietzsche's eternal return must be understood as a principle of difference and its reproduction or, in other words, difference and repetition. Nietzsche calls this principle the will to power. The will to power is at once complementary and inherent to force. The will to power is not ascribed to forces as a predicate, but a differential element in their relationship: "The will to power is the element from which derive both the quantitative difference of related forces and the quality that devolves into each force in this relation." 43 Therefore, the will to power is a differential and genetic element of forces, whereby it is added as the internal principle of determining the quality of the relationship of forces and of determining the relationship itself. Briefly, the will to power is a principle of the intensity of forces. Further, the terms "active" and "reactive" determine the qualities of forces, whereas the terms "affirmation" and "negation" determine the qualities of the will to power, wherein lies the ethical aspect of Deleuze's Nietzsche.

Namely, affirmation and negation precisely define becoming: "Affirmation is not action but the power of becoming active, becoming active personified. Negation is not simple reaction but a becoming reactive. It is as if affirmation and negation were both immanent and transcendent in relation to action and reaction;

\footnotetext{
${ }^{40}$ Ibid.

${ }^{41}$ Cf. ibid., 42.

${ }^{42}$ Ibid., 45-46.

${ }^{43}$ Ibid., 50, emphasis in the original.
} 
out of the web of forces they make up the chain of becoming." ${ }^{44}$ And the will to power is that which assesses and determines the quality of forces that constitute becoming as its active and reactive, affirmative or negative elements. In that sense, the will to power is genealogic, because it assesses the origins and quality of forces that constitute things and values. Negation qua becoming reactive rests on the forces of adaptation. Also, it puts limits on active forces regarding what they can do. On the other hand, affirmation qua becoming active is a dominant force that goes to the very limits of what it can do, a force that affirms the difference "which makes its difference an object of enjoyment and affirmation". ${ }^{45}$ Therein lies the ethical aspect of Deleuze's Nietzsche - finding ways of becoming, a becoming comprising forces and only forces, so as to affirm difference qua difference, to affirm immanence, through acting, at the expense of every possible transcendence, even that of capital under the conditions of the relative immanence of capitalism:

However, immanence in capitalism is restricted. Why? [...] Capital harnesses its power from dialectics, but it is also a regent-guardian-bodyguard of dialectical operations, it is, finally, an endless cycle that keeps reverting to itself, only to start from itself anew. It seems that capital, nevertheless, may not be separated from the effects of transcendence: the "capital-god", from whom springs everything, transcends his own immanent domains, floats above immanence, creates a sky over and above the void of immanence, and reigns from above. Capital is the transcendent God the Father, a paternalistic structure in the framework of relative immanence; in this context, one may only speak of immanence toward something, not of absolute immanence... ${ }^{46}$

In lieu of the inorganic vitality of absolute immanence, which, among other things, constitutes the body as a physical system, the reactive working of forces supplies the body as a well-ordered organism; every part of that organism has a predetermined function under the conditions of the relative immanence of the capitalist axiomatic, which, as discussed above, comprises a certain number of axioms and two aspects - machinic enslavement and social subjection - which give rise to the formation of the body according to the demands of the axiomatic. Organs presuppose a hierarchical model of the body and reproduce the prob-

\footnotetext{
${ }^{44}$ Ibid., 54, emphasis in the original.

${ }^{45}$ Ibid., 61.

${ }^{46}$ Alpar Lošonc, "Politizacija imanencije; politizacija posredstvom imanencije" (The Politicization of Immanence; Politicization through Immanence), in: Kristina Bojanović (ed.), Slike mišljenja Žila Deleza (Images of Gilles Deleuze's Thought), Nikšić, Montenegro, Društvo filosofa Crne Gore, 2011, 58-59.
} 
lems of its unity, individuality, and organization. ${ }^{47}$ In other words, organs, like the subject, presuppose unity as an a priori principle and the One as the ontological foundation of the present, while the body is formed on the basis of the preindividual and supra-individual field of singularity and intensive difference. As a subject of organic representation, the subject rests on recognition as a transcendental model (the subjection of difference to the identity of concept, the opposition of predicates, the analogy of judgment, and similarity of perception), which constitutes a complex system of the image of thought, along with common sense and the senses. This establishes a model of harmonizing faculties that are rooted in the thinking subject as the universal subject, ${ }^{48}$ whereby difference in itself, as the de-founding basis of event, is subjected to identity and the possibility of a sensory encounter with that which forces one to think is lost. ${ }^{49}$ In Difference and Repetition, Deleuze distinguishes between "bare" and "disguised" repetition..$^{50}$ In "bare" repetition, "the difference is taken to be only external to the concept; it is a difference between objects represented by the same concept, falling into the indifference of space and time", ${ }^{51}$ the repetition of the Same, that "explained by the identity of the concept or representation", 52 it is negative in the absence of concept, hypothetical, revolutionary, it belongs to equality, commensurability, and symmetry, it is material, lifeless. ${ }^{53}$ Unlike, or, rather, inside and behind "bare" repetition, lies repetition qua difference itself, unmediated difference that gives rise to repetition.

So where does this mutual determination of minimal music and "the opinion of an average capitalist" come from? How does minimal music merely repeat the clichés of the already lived and thereby merely confirms perceptions of the body $q u a$ organism? The answer lies in the interrelating of minimal music and neutral sensation, that is, in the "natural" body and works that minimalism produces. On the one hand, by insisting on a merely corporeal perception of sound ("art is the very act of perceiving"), minimal music does not break with the lived, but only confirms it. In turn, by confirming it, minimal music also confirms all that such a perception brings along, which comprises the entire content that a well-

${ }^{47}$ Cf. Anne Sauvagnargues, Deleuze and Art, London and New York, Bloomsbury Academic, 2013, 58.

${ }^{48}$ Cf. Gilles Deleuze, Difference and Repetition, London and New York, Continuum, 2001, 134.

${ }^{49}$ Cf. ibid., 139.

${ }^{50}$ Cf. ibid., 24.

${ }^{51}$ Ibid., 23-24.

${ }^{52}$ Ibid., 24.

${ }^{53}$ Cf. ibid. 
ordered body-organism and subject of an organic idea receive due to the relative immanence of capitalism. In other words, minimal music merely reproduces, or produces perception identical to that which the capitalist mode of production has already produced. Minimalism does not bring a break with the "natural" flow of perceptions, but only follows already established and coded fluxes, whereby it remains in the image of thinking that supplants difference with identity. The neutrality of the sort of subject that minimalism holds dear generates "democratic sensations structuring a common flesh", ${ }^{54}$ but precisely for that same reason, minimalism is unable to generate resistance to contemporary social conditions and forms of life. By focusing on perception itself, minimalism emphasizes the viewer and listener's bodily engagement, their ability to notice a change in their experience, and thus also the artwork's bodily and visual-aural effect. In fact, it thereby introduces a division between an empirical-psychological and transcendental plane, whereby minimalist works of art become representations with explicit elements of their own constitution; those elements are syntheses of a multitude of perceptions, the contingency of embodiment, and relations between the object and the environment. Minimalism, therefore, leads from a "naïve" empirical $I$ to a neutral subject. Thus, it is bare repetition, one that makes no difference.

\footnotetext{
${ }^{54}$ Stephen Zepke, "Deleuze, Guattari, and Contemporary Art", in: Eugene W. Holland, Daniel W. Smith, and Charles J. Stivale (eds.), Gilles Deleuze: Image and Text, London and New York: Continuum, 2009, 180.
} 